\title{
Chubby mothers-maternal and perinatal outcome in high body mass index
}

\author{
Kavitha Garikapati*, K. B. Gayathri, K. Naga Lalitha
}

Department of Obstetrics and Gynaecology, Dr. PSIMS and RF, Gannavaram, Krishna Dt, Andhra Pradesh, India

Received: 19 March 2021

Accepted: 12 April 2021

\section{*Correspondence:}

Dr. Kavitha Garikapati,

E-mail: kavithagarikapati4@gmail.com

Copyright: (c) the author(s), publisher and licensee Medip Academy. This is an open-access article distributed under the terms of the Creative Commons Attribution Non-Commercial License, which permits unrestricted non-commercial use, distribution, and reproduction in any medium, provided the original work is properly cited.

\begin{abstract}
Background: Obesity is a state of excess adipose tissue mass. Body mass index (BMI) is a crucial predictor of nutritional status of pregnant women. High BMI may lead to various adverse maternal and perinatal outcomes. This study is designed to see the effect of maternal BMI on pregnancy outcome and perinatal outcome according to Asian standards.

Methods: This is an institutional retrospective, descriptive study of 100 pregnant women conducted in the department of obstetrics and gynaecology of a rural tertiary centre Dr. PSIMS and RF, Chinaoutpalli, Gannavaram, Vijayawada, AP, India from June 2017 to July 2019.

Results: It was observed that as BMI increased risk of complications increased like hypertension disorders in pregnancy, gestational diabetes mellitus, preterm labour. Also risk of macrosomia, operative delivery, Neonatal intensive care unit (NICU) admissions increased.

Conclusions: As maternal BMI is a good predictor has strong correlation with pregnancy complications and outcomes, measures should be taken to motivate for pre pregnancy counselling regarding weight management and close surveillance in antenatal period to diagnose at the earliest any complications.
\end{abstract}

Keywords: Body mass index, Macrosomia, Caesarean section, Pre-eclampsia, Neonatal intensive care unit

\section{INTRODUCTION}

Obesity is the state of excess adipose tissue mass. Adipose mass increases by enlargement of adipose cells as well as by increase in number of adipocytes. ${ }^{1}$

A healthy foetus from a healthy mother was coined by Sir Julius Huxley. The global safe motherhood initiative launched in 1987, is designed to improve antenatal care and counselling throughout the world. Obesity causes or exacerbates many health problems, both independently and in association with other diseases. ${ }^{2}$

Pregnancy by itself alters the physiology in women, which increase many medical problems increasing the morbidity and mortality if not supervised and managed accordingly. The prevalence of obesity on raise in young women in the recent world which has a major impact on the reproductive outcomes, which have been documented by several researchers.

The raising rate of obesity is a major public health concern more so in the developing countries like India as very few females come for pre conceptional counselling, and so pre pregnancy weight record is not available and thus the women even from rural areas are unaware of their weights. ${ }^{3}$

Obesity is an independent as well as associated risk factor which causes or exacerbates many health problems. It is associated with development of type 2 diabetes mellitus, coronary heart disease, and increased incidence of cancer, respiratory complications and osteoarthritis of large and small joints in the later years. ${ }^{4}$ 
Obese pregnant women are at increased risk for an array of maternal and perinatal complications and the risks accomplished with increasing degree of maternal obesity. 5,6

It has been estimated that, quarter of pregnancy complications like gestational hypertension, preeclampsia, gestational diabetes, preterm birth is attributable to excess gestational weight gain. ${ }^{6}$

The worldwide obesity epidemic continues to be a major public health challenge particularly in women of child bearing age..$^{7-9}$

BMI calculation values vary in developed and in developing countries. BMI calculation based on Asian standards have low cut off value than that given by WHO.

In our study, we classified patients with BMI, according to Asian standards and studied correlation with complications, maternal and perinatal outcome.

\section{METHODS}

This present study is an institutional retrospective, descriptive study of 100 pregnant women conducted from June 2017 to July 2019. In the department of obstetrics and gynaecology of a rural tertiary centre PSIMS and RF, Chinaoutpalli, Gannavaram, Vijayawada, AP, India.

Data is collected from the case sheets, traced through medical record department and classified according to their BMI in Asian standards and pregnancy complications, maternal and perinatal outcomes studied. Statistical analyses done by MS excel software.

Table 1: Asian standards for classification of BMI.

\begin{tabular}{|ll|}
\hline BMI $\left(\mathrm{kg} / \mathrm{m}^{2}\right)$ & Interpretation \\
\hline $\mathbf{1 1 8 . 5}$ & Underweight \\
\hline $\mathbf{1 8 . 5 - 2 2 . 9}$ & Normal \\
\hline $\mathbf{2 3 - 2 4 . 9}$ & Overweight \\
\hline $\mathbf{2 2 5}$ & Obese \\
\hline
\end{tabular}

Table 2: WHO standards for classification of BMI.

\begin{tabular}{|ll|}
\hline BMI $\left(\mathrm{kg} / \mathrm{m}^{\mathbf{2}}\right)$ & Interpretation \\
\hline $\mathbf{1 1 8 . 5}$ & Under weight \\
\hline $\mathbf{1 8 . 5 - 2 4 . 9}$ & Normal \\
\hline $\mathbf{2 5 - 2 9 . 9}$ & Over weight \\
\hline $\mathbf{3 0}$ & Obese \\
\hline $\mathbf{3 0 - 3 4 . 9}$ & Class 1 obese \\
\hline $\mathbf{3 5 - 3 9 . 9}$ & Class 11 obese \\
\hline $\mathbf{2 4 0}$ & Class 111 obese \\
\hline
\end{tabular}

Inclusion criteria is Singleton pregnancy, age $>20$ years and $<35$ years, BMI $>18.5 \mathrm{~kg} / \mathrm{m}^{2}$
Exclusion criteria is multiple pregnancy, age $<20$ years and >35 years, pre-existing comorbidities like hypertension, overt diabetes, SLE etc.

Antenatal women were categorised into 3 groups according to their BMI as follows (on the basis of Asian standards).

\section{RESULTS}

Figure 1 shows sample size is 100 antenatal women. Normal BMI 26 women (26\%), overweight 24 women $(24 \%)$ and obese 50 women $(50 \%)$

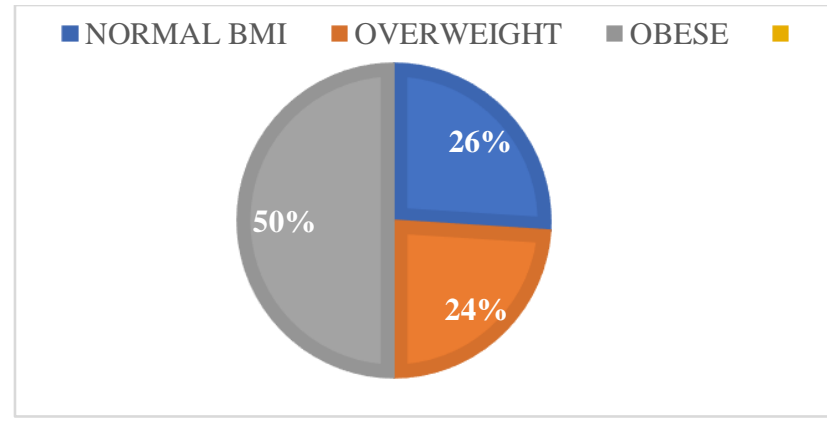

Figure 1: Sample size according to Asian classification of BMI.

Table 3: BMI and pregnancy outcome.

\begin{tabular}{|llll|}
\hline $\begin{array}{l}\text { Pregnancy } \\
\text { outcome }\end{array}$ & $\begin{array}{l}\text { Normal, } \\
(\mathbf{n = 2 6}) \\
(\%)\end{array}$ & $\begin{array}{l}\text { Overweight, } \\
(\mathbf{n = 2 4}) \\
(\%)\end{array}$ & $\begin{array}{l}\text { Obese, } \\
(\mathbf{n}=50) \\
(\%)\end{array}$ \\
\hline $\begin{array}{l}\text { Gestational } \\
\text { hypertension }\end{array}$ & 00 & 00 & $3(6)$ \\
\hline $\begin{array}{l}\text { Pre-eclampsia } \\
\text { Eclampsia }\end{array}$ & $1(3.84)$ & $3(12.5)$ & $14(28)$ \\
\hline $\begin{array}{l}\text { Gestational } \\
\text { diabetes }\end{array}$ & 0 & 00 & $2(4)$ \\
\hline $\begin{array}{l}\text { Hypertensive } \\
\text { retinopathy }\end{array}$ & 0 & $2(8.33)$ & $5(10)$ \\
\hline Preterm labor & $2(7.69)$ & $1(4.16)$ & $5(10)$ \\
\hline
\end{tabular}

Table 3 shows in our study, we had 3 cases of preeclampsia, 2 cases of GDM and one preterm labour in overweight group. Whereas 20 cases of hypertension disorders in pregnancy along with hypertensive retinopathy and 5 cases of GDM in obese group which indicate as BMI increases, pregnancy complications increase.

Table 4: BMI and mode of delivery.

\begin{tabular}{|llll|}
$\begin{array}{l}\text { Mode of } \\
\text { delivery }\end{array}$ & $\begin{array}{l}\text { Normal, } \\
(\mathbf{n = 2 6})\end{array}$ & $\begin{array}{l}\text { Overweight, } \\
(\mathbf{n}=\mathbf{2 4})\end{array}$ & $\begin{array}{l}\text { Obese, } \\
(\mathbf{n}=50)\end{array}$ \\
\hline Vaginal & $18(69.2)$ & $20(83.3)$ & $18(36)$ \\
\hline LSCS & $7(26.9)$ & $4(16.6)$ & $28(56)$ \\
\hline Instrumental & $1(3.84)$ & 0 & $4(8)$ \\
\hline
\end{tabular}


Table 4 shows in our study, vaginal delivery rate is decreasing and caesarean section rate is increasing with increasing body mass index. Caesarean section rate increased to $56.6 \%$ and instrumental delivery rate is $8 \%$ in obese women. Incidence of caesarean section rate doubled in obese when compared to normal body mass index.

Table 5: BMI and perinatal outcome.

\begin{tabular}{|llll|}
\hline $\begin{array}{l}\text { Perinatal } \\
\text { outcome }\end{array}$ & $\begin{array}{l}\text { Normal, } \\
(\mathbf{n = 2 6}) \\
(\%)\end{array}$ & $\begin{array}{l}\text { Overweight, } \\
(\mathbf{n = 2 4}) \\
(\%)\end{array}$ & $\begin{array}{l}\text { Obese, } \\
(\mathbf{n = 5 0}) \\
(\%)\end{array}$ \\
\hline $\begin{array}{l}\text { Preterm } \\
\text { birth }\end{array}$ & $2(7.69)$ & $1(4.16)$ & $5(10)$ \\
\hline $\begin{array}{l}\text { Stillbirth } \\
\text { IUD }\end{array}$ & 0 & 0 & 0 \\
\hline APGAR & 0 & 0 & 0 \\
\hline $0-3$ & 0 & 0 & 0 \\
\hline $4-6$ & $1(3.84)$ & 0 & $1(2)$ \\
\hline $7-10$ & $25(96.15)$ & $24(100)$ & $49(98)$ \\
\hline $\begin{array}{l}\text { NICU } \\
\text { admissions }\end{array}$ & $1(3.84)$ & $2(8.33)$ & $17(34)$ \\
\hline $\begin{array}{l}\text { Perinatal } \\
\text { mortality }\end{array}$ & 0 & 0 & 0 \\
\hline Birth weight & $(\mathbf{k g})$ & & \\
\hline$\leq 2$ & 0 & 0 & $1(2)$ \\
\hline $2.0-2.49$ & $1(3.84)$ & $3(12.5)$ & $5(10)$ \\
\hline $2.5-2.99$ & $13(50)$ & $11(45.83)$ & $16(32)$ \\
\hline $3.0-3.49$ & $12(46.1)$ & $10(41.6)$ & $22(44)$ \\
\hline $3.5-3.99$ & 0 & 0 & $3(6)$ \\
\hline $4-4.49$ & 0 & 0 & $3(6)$ \\
\hline
\end{tabular}

Table 5 shows risk of macrosomia, preterm birth and NICU admission increased with increased body mass index. Macrosomia in 12\%, NICU admissions $34 \%$, preterm birth $10 \%$ in obese women. There is no perinatal mortality.

Table 6: BMI and maternal morbidity.

\begin{tabular}{|llll|}
\hline $\begin{array}{l}\text { Maternal } \\
\text { morbidity }\end{array}$ & $\begin{array}{l}\text { Normal, } \\
(\mathbf{n = 2 6}) \\
(\%)\end{array}$ & $\begin{array}{l}\text { Overweight, } \\
(\mathbf{n = 2 4}) \\
(\%)\end{array}$ & $\begin{array}{l}\text { Obese, } \\
(\mathbf{n}=50) \\
(\%)\end{array}$ \\
\hline $\begin{array}{l}\text { Wound } \\
\text { infections }\end{array}$ & 0 & $1(4.16)$ & $2(4)$ \\
\hline $\begin{array}{l}\text { Secondary } \\
\text { suturing }\end{array}$ & 0 & $1(4.16)$ & $2(4)$ \\
\hline DVT & 0 & 0 & 0 \\
\hline $\begin{array}{l}\text { Blood } \\
\text { transfusions }\end{array}$ & $1(3.84)$ & $2(8.33)$ & $2(4)$ \\
\hline
\end{tabular}

Table 6 shows rate of wound infections and secondary suturing increased with body mass index. Due to high body mass index, rate of wound infections, secondary suturing is increased. PPH is seen in $8.33 \%$ in overweight and $4 \%$ of obese women due to prolonged labor and atonicity.

\section{DISCUSSION}

A number of systems have been used to define and classify obesity. The BMI also known as Quetelet index, is currently most often used. The BMI is calculated as weight in kilograms divided by square of the height in meters $\left(\mathrm{kg} / \mathrm{m}^{2}\right)$.

In our present study, 100 pregnant women who attended antenatal OPD at Dr. PSIMS and RF were included who met with inclusion and exclusion criteria.

They were classified based on Indian standards: Overall distribution of cases-Normal weight-26\%, over weight$24 \%$, obese- $50 \%$. then the outcome is also compared with WHO standards.

In our present study, maternal outcomes such as preeclampsia was seen in normal weight (3.84\%), overweight $(12.5 \%)$ and obese $(28 \%)$ pregnant women but if we take according to WHO standard, preeclampsia was seen in $31.5 \%$ of women with pre-obesity, $20 \%$ in obese I , $42.8 \%$ in obese II, $25 \%$ in obese III. In another study carried by Santos et al, preeclampsia was seen in $34.6 \%$ of women with maternal overweight and obesity (according to WHO). ${ }^{10}$ In present study and the other study conducted by Bhushan et al, preeclampsia was found to be significant in women with high BMI. ${ }^{14}$

If we take according to WHO standards, we would miss 4 cases $(16.34 \%)$ of pre-eclampsia cases undiagnosed. Gestational hypertension was $6 \%$ in obese women (Asian standards). Study carried out by Santos et al, the percentage was increased to $35.6 \%$ with obese women (WHO). ${ }^{10}$

If we take WHO standards as obese, we would have missed $6 \%$ as they fall under normal BMI.

Present study shows increase in percentage of gestational HTN with increase in BMI correlating with the study conducted by Bhushan et al. ${ }^{14}$

Another study conducted by Bhuvaneshwari et al gestational hypertension was found in $33 \%$ of obese women followed by overweight $9 \% .^{15}$

GDM in present study was seen in $18.33 \%$ in overweight and obese (Asian), whereas it is $34.46 \%$ (WHO).

Similar studies done by Santos et al, the risk of GDM in obese and overweight women was $42.8 \%$. Therefore, DM is associated with increasing overweight and obesity (WHO). ${ }^{10}$

In study by Bhuvaneshwari et al, gestational diabetes was found in $13 \%$ in obese women followed by overweight women $7 \% .{ }^{15}$ In another study conducted by Ramya et al GDM was found in $13 \% .^{16}$ 
If we take WHO standards, we would miss 4\% of GDM.

The risk of preterm labor was increased from $10.5 \%$ in pre-obese women to $28.5 \%$ in obese II women and $25 \%$ in obese class III according to WHO, whereas it is $4.16 \%$ in overweight and $10 \%$ in obese women according to Indian standards but it has got no significance in studies conducted by Santos et al. ${ }^{10}$

Bhuvaneshwari et al in their study found that preterm labor was seen in obese $11 \%$ and overweight $6 \% .^{15}$

We would miss 3 cases, if WHO standards considered.

Caesarean section rate has increased from $16.6 \%$ in overweight women to $56 \%$ in obese women according to Indian standards, whereas it is $51.6 \%$ in preobese, $45 \%$ in obese class I, $71.4 \%$ in obese class II and $50 \%$ in obese class III women. Dr. Bhubaneshwar et al reported caesarean delivery in $55 \%$ obese women which correlated with our study ${ }^{15}$

Similar studies were seen with Bhushan et al and Ramya et al where the risk of caesarean sections and instrumental deliveries increases significantly with increase in BMI. ${ }^{14,16}$ Another study conducted by Lisonkaya et al obese women had higher rate of caesarean delivery, previous LSCS, labor induction rates (WHO). ${ }^{9}$

The rate of instrumental delivery was $25 \%$ in obese III individuals according to WHO standard.

Regarding perinatal outcome in our present study, as BMI increases, there was increase in birth weight of baby, correlating with studies of James et al and Kumar et al. ${ }^{3,13}$

Bhubaneshwar et al in her study found that babies $>3.5$ $\mathrm{kg}$ were seen in obese women $(22 \%)$ followed by overweight women $5.2 \%$ which correlates with our study. ${ }^{15}$

The average Apgar score at 5min was 7-10 in $100 \%$ of babies with overweight mother and $98 \%$ of babies with obese mothers. There is no correlation between BMI and APGAR score in our study which correlates with study conducted by Ramya et al. ${ }^{16}$

The rate of NICU admission was $34 \%$ in babies with obese mother according to Indian standards, which correlates with study conducted by Bhubaneshwar et al where NICU admissions was seen in $33 \%$ of obese women. ${ }^{15}$ Similar studies are seen with Bhushan et al and Ashok Kumar et al where the number of NICU admissions increased significantly with increase in BMI. ${ }^{13,14}$

There was no stillbirth, IUD, maternal mortality in our study. The study of effect of maternal BMI shows strong association with adverse maternal and perinatal outcome.
Hence adequate pre conceptional counselling is necessary to attain normal BMI and meticulous antenatal care to screen, diagnose and treat medical disorders. Proper intrapartum and postpartum care to decrease morbidity has to be taken. Obesity is a modifiable risk factor. High BMI is associated with dyslipidaemia, Type 2 DM and chronic hypertension in future. So, maintaining physical health is the first step to prevent the morbidity.

\section{Limitations}

With good sample size more significant outcome would be measured.

\section{CONCLUSION}

Asian population have different ethnicity, stature, socio economic status and there is every chance of missing the cases undiagnosed if we take WHO criteria for BMI calculation, which may lead to adverse maternal and perinatal outcome. So, Asian standards may have to be considered for calculating BMI and thus counselling and managing the cases.

\section{ACKNOWLEDGMENTS}

Author would like to thank to HOD, OBGYN dept, Dr. PSIMS and RF and medical superintendent for allowing me to do this study and thank all the medical and paramedical staff and departmental stenographer who have helped me complete this study.

Funding: No funding sources

Conflict of interest: None declared

Ethical approval: The study was approved by the Institutional Ethics Committee

\section{REFERENCES}

1. World Health Organisation. Diet, nutrition and the prevention of diseases: report of a joint WHO/FAO expert consultation. Technical report series 916. Geneva, Switzerland: World Health Organisation. 2002. Available at: https://www.who.int/diet physicalactivity/publications/trs916/en/. Accessed on 3 January 2021.

2. Kopelman PG. Causes and consequences of obesity. Med Int. 1994;22:385-8.

3. James WP. WHO recognition of the global obesity epidemic. Inj J Obs (Lond). 2008;32(7):20-6.

4. Haslam DW, James WP. Obesity. Lancet. 2005;366:1197-209.

5. Kopelman PG. obesity as a medical problem. Nature 2006:404.

6. Malik VS, Willett WE, Hu FB. Global obesity trends, risk factors and policy implications. Mart Rev endocrinol. 2013;9(1):13-27.

7. Catalano PM, Shankar K. Obesity and pregnancy, mechanisms of short term and long-term adverse 
consequences for mother and child. BMJ. 2017;356:1.

8. Torlani MR, Betran AP, Hota BL. Prepregnancy BMI and risk of gestational diabetes a systematic review of the literature with meta-analysis. Obes Rev. 2009;10-194.

9. Lisonkoya S, Muraca GM, Potts J. Associates between pre-pregnancy Body mass index and severe. Maternal morbidity. 2017;318:1777.

10. Santos S, Voerman E, Amiano P. Impact of maternal body mass index and gestational weight gain on pregnancy complications :an individual participant data meta-analysis of European, North American and Australian cohorts. BJOG. 2019;126:984.

11. Gunatilake RP, Perlow JH. Obesity and pregnancy: clinical management of the obese gravid. Am J Obstet Gynecol. 2011:204:106.

12. ACOG Practice Bulletin No 156: Obesity in pregnancy. Obstet Gynecol. 2015;126:e112.

13. Kumar HAS, Chellamma VK. Effect of Maternal Body Mass Index on Pregnancy Outcome. Int J Sci Stud 2017;4(10):81-4.
14. Bhushan N, Surinder K, Dinesh K, Khajuria R. The impact of maternal body mass index on maternal and perinatal outcome. Int J Reprod Contracept Obstet Gynecol. 2017;6:2862-6.

15. Bhuvaneshwari K, Gayathri. N, Prema Priya G, Dhingra S, Vimala D. A study on pre pregnancy body mass index and its effect on maternal and perinatal outcome. Obs Rev: J obstet Gynecol. 2019:5(4):181-85.

16. Ramya S, Kumar A, Sharan S, Ramaiah R. A study of body mass index in pregnancy and its correlation with maternal and perinatal outcome. New Indian $\mathbf{J}$ Obgyn. 2019:5(2):120-5.

Cite this article as: Garikapati $\mathrm{K}$, Gayathri $\mathrm{KB}$, Lalitha KN. Chubby mothers-maternal and perinatal outcome in high body mass index. Int J Reprod Contracept Obstet Gynecol 2021;10:1809-13. 